\title{
Protein intakes and sources in diets of infants and young children aged 6-18 months in the United Kingdom
}

\author{
A. Sidnell and R. Long \\ Nestle Nutrition, 1 City Place, Gatwick, RH6 OPA
}

Childhood obesity is of concern, with over a fifth of children in the UK starting school either overweight or obese ${ }^{(1)}$. The early protein hypothesis suggests that excess protein intake in infancy is a risk factor for overweight and obesity in later childhood ${ }^{(2)}$. During the complementary feeding period there is a rapid increase in protein intake ${ }^{(2)}$. High animal protein intake at 12 months, in particular from dairy sources, has been associated with an unfavourable body composition at 7 years of age ${ }^{(2)}$. It has been suggested that protein as a percentage of energy intake should not exceed $15 \%$ in infants 12 months old, as higher than this may be associated with a higher risk of obesity in later life ${ }^{(3)}$. Using the Diet and Nutrition Survey of Infants and Young Children ${ }^{(4)}$ this descriptive analysis reports protein intake and sources in 6 to 18 month olds in the UK, and compares intakes to the RNI ${ }^{(5)}$.

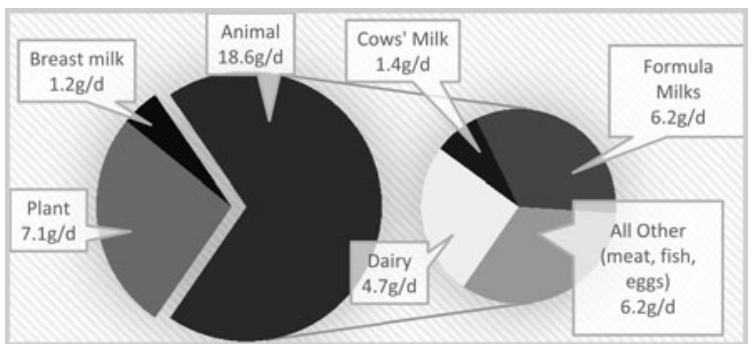

Fig. 1. Mean protein intake from different sources among infants 6 to $<12$ months

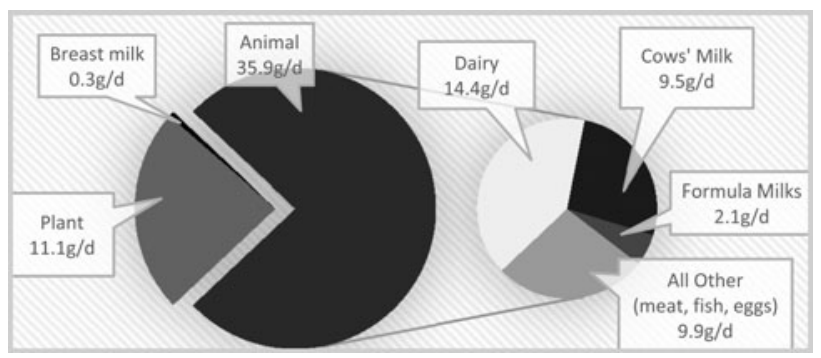

Fig. 2. Mean protein intake from different sources among infants 12 to 18 months

\begin{tabular}{|c|c|c|c|c|c|c|c|c|c|c|}
\hline & \multicolumn{5}{|c|}{$6-12$ months } & \multicolumn{5}{|c|}{$12-18$ months } \\
\hline & Mean & Median & $25^{\text {th }} \%$ & $75^{\text {th }} \%$ & $95^{\text {th }} \%$ & Mean & Median & $25^{\text {th }} \%$ & $75^{\text {th }} \%$ & $95^{\text {th }} \%$ \\
\hline Protein intake (g/d) & $25 \cdot 5$ & $24 \cdot 2$ & $19 \cdot 2$ & $30 \cdot 4$ & $41 \cdot 8$ & $37 \cdot 7$ & $37 \cdot 5$ & $30 \cdot 7$ & $44 \cdot 3$ & 54.9 \\
\hline (\% kcal) & $13 \%$ & $12 \%$ & $11 \%$ & $13 \%$ & $15 \%$ & $16 \%$ & $16 \%$ & $15 \%$ & $16 \%$ & $17 \%$ \\
\hline
\end{tabular}

At 6 to $<12$ months, mean energy intake was $801 \mathrm{kcal} /$ day, mean protein intake $25.5 \mathrm{~g} /$ day ( $13 \%$ of energy), while at 12 to 18 months mean energy intake was $967 \mathrm{kcal} /$ day, and protein $38 \mathrm{~g} /$ day (16\% energy). Mean protein intakes were $70 \%$ and $150 \%$ higher than the RNI at 6 to $<12$ months, and 12 to 18 months respectively. Major sources of protein were formula milks, cows' milk and other dairy products. Protein contribution from cows' milk rose from $6 \%$ at 6 to $<12$ months to $25 \%$ at $12-18$ months. Cows' milk contributes valuable nutrients to the diet, but the possible implications of this large increase in animal protein intake should be considered. Future research is needed to understand the implication of reducing protein intakes in early life on long-term health.

1. Public Health England (2016) National Child Measurement Programme. http://www.noo.org.uk/NCMP (accessed $3^{\text {rd }}$ March 2017).

2. Gunther AL, Remer T, Kroke A et al. (2007) Early protein intake and later obesity risk: Which protein sources at which time points throughout infancy and childhood are important for body mass index and body fat percentage at 7 y of age? Am J Clin Nutr 86, Suppl. 6, $1765-1772$.

3. Pimpin L, Jebb S, Johnson L et al. (2016) Dietary protein intake is associated with body mass index and weight up to $5 \mathrm{y}$ of age in a prospective cohort of twins. Am J Clin Nutr 103, 389-397.

4. Lennox A, Sommerville J, Ong K et al. (2013) Diet and Nutrition Survey of Infants and Young Children, 2011. https://www.gov.uk/government/ publications/diet-and-nutrition-survey-of-infants-and-young-children-2011 (accessed $3^{\text {rd }}$ March 2017).

5. Department of Health (1991) Dietary Reference Values for Food Energy and Nutrients for the United Kingdom. London: HMSO. 